\title{
A teoria da história em Caio Prado Jr.: dialética e sentido
}

\section{Jorge Grespan ${ }^{1}$}

\section{Resumo}

Este artigo analisa as obras em que Caio Prado Jr. trata de temas de metodologia e filosofia, buscando entender, em primeiro lugar, como ele formulava os principais conceitos da dialética e como os vinculava à tradição filosófica, especialmente a de Hegel e de Marx. Em segundo lugar, a partir deste contexto é analisado o conceito de sentido em sua riqueza dialética, para daí entender sem reducionismos como ele aparece na obra do historiador.

\section{Palavras-chave}

Filosofia, Dialética, Sentido, Hegel, Marx, História

1 Professor de Teoria da História no Departamento de História da Faculdade de Filosofia, Letras e Cièncias Humanas da Universidade de São Paulo.

E-mail: grespan@usp.br 


\section{Caio Prado Jr's Theory of History: dialetics and meaning}

\section{Jorge Grespan}

\section{Abstract}

This article analyzes the works in which Caio Prado Jr. deals with methodological and philosophical issues, trying to understand in first place how he formulated the main concepts of dialectics and how he linked them to philosophical tradition, specially that of Hegel and of Marx. Secondly, in this context the concept of meaning is analyzed in its full dialectical complexity, and only then its non-reductionist understanding in the historians work could be achieved.

\section{Keywords}

Philosophy, Dialectics, Meaning, Hegel, Marx, History 


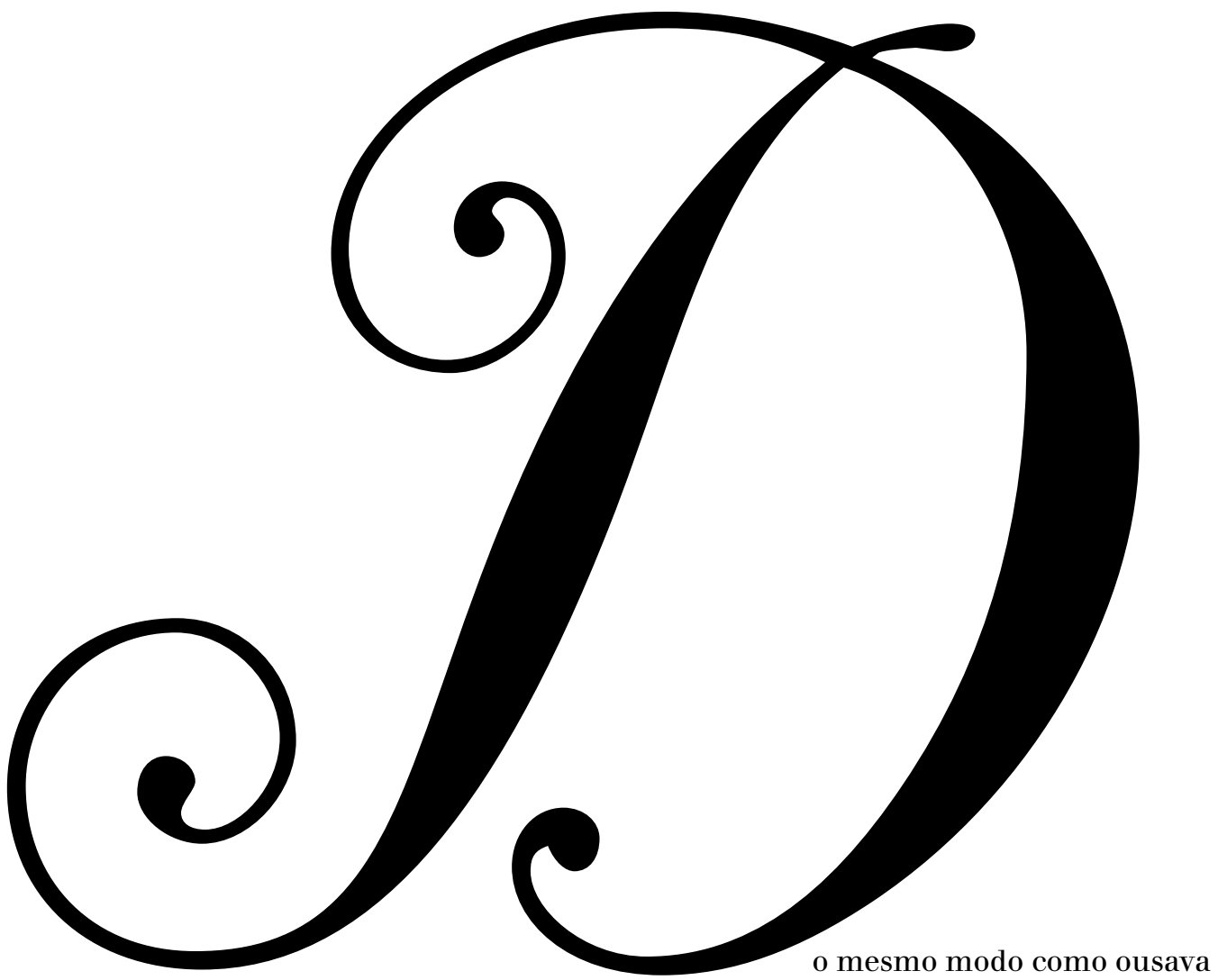

propor teses originais sobre a realidade brasileira, Caio Prado Jr. foi o único intelectual marxista da sua geração que por aqui se aventurou a estudar e a escrever sobre "lógica dialética". Antes do surgimento do marxismo na universidade, entre os anos 1950 e 1960, tais assuntos, como quase todos de âmbito teórico, eram considerados problemas que os fundadores europeus da doutrina já teriam resolvido. Os seguidores brasileiros deviam somente aplicá-los na prática política.

Caio Prado se interessava por lógica e metodologia desde os anos 1930. Mas talvez tenha decidido concentrar-se no estudo da dialética apenas quando sentiu a necessidade de defender suas posições: a interpretação original do Brasil e a própria divergência, derivada dessa interpretação, em relação à política oficial do Partido Comunista Brasileiro (PCB).

Nesse sentido, pode ser sintomático que Dialética do conhecimento, de 1952, tenha sido a primeira grande publicação de Caio Prado desde a História econômica do Brasil em 1945. Alguns estudiosos de sua obra chegam a distinguir nesse momento a passagem para uma segunda fase: não seria mais preciso, como nos anos 1930 e 1940, elaborar uma nova visão do Brasil que o arrancasse do atraso econômico e político típico da República Velha; 
nos anos 1950 esta visão estaria mais ou menos consolidada, e a tarefa passava a ser a redefinição do modo pelo qual o país se inseria no mundo².

Pode ser. $\mathrm{O}$ inegável é que o debate havia mudado de patamar. Várias instituições novas surgiam, como o Instituto Superior de Estudos Brasileiros (ISEB) e o sistema de universidades públicas; e mesmo no PCB a formulação das estratégias agora pedia referências a um quadro mais amplo. A interpretação da história brasileira proposta entre 1933 e 1945 por Caio Prado passava a concorrer com outras relativamente próximas do seu espectro político. A disputa demandava exatidão conceitual, clareza nos fundamentos.

\section{Sentido da dialética}

De fato, Caio Prado chega a mencionar, no primeiro capítulo de um livro posterior sobre o tema - Notas introdutórias à lógica dialética, de 1959 -, que o tratamento dado por ele à questão em 1952 suscitara objeções: "Depois da publicação da Dialética do conhecimento, tive bem a medida dessas dúvidas e confusões, chegando alguns críticos a me acusarem de 'hegeliano' e ‘idealista' porque fazia da Dialética uma Lógica, e portanto um fato mental!" ${ }^{3}$. Ele trata então de esclarecer o leitor sobre os "dois sentidos da expressão" dialética, que designaria tanto "o comportamento geral da Natureza [...], a mutabilidade e instabilidade de suas feições, a permanente transformação delas", quanto um método de considerar a realidade. Um "sentido" objetivo e outro subjetivo, podemos dizer, que "se entrosam intimamente", mas "são distintos".

Temos aqui já alguns pontos importantes. O primeiro é a concepção da realidade marcada pela "permanente transformação", pela "mutabilidade", o que introduz a discussão sobre a história e a historicidade do real. O segundo é a relação entre os dois sentidos da dialética, isto é, o modo como se "entrosa" o que é "distinto". Finalmente, mesmo levando em conta tratar-se de um desaforo tradicional na disputa política comunista, o fato de Caio Prado ter sido acusado de "hegeliano" pode ser índice de algo interessante, de uma concepção mais fina de dialética que caberia investigar.

De qualquer modo, é preciso começar admitindo que esta concepção geral da dialética como "comportamento da Natureza" não é inovadora, constituindo um dos pilares do marxismo como doutrina elaborada por

2 Cf., por exemplo: RICUPERO, Bernardo. Caio Prado Jr. e a nacionalização do marxismo no Brasil. São Paulo: Ed. 34, 2000. p. 118-119.

3 PRADO JR., Caio. Notas introdutórias à lógica dialética. São Paulo: Brasiliense, 1959. p. 5 , nota 1 .

4. Ibidem, grifos meus. 
Engels e consagrada pela União Soviética. Nos termos do debate então em curso, aliás, nem poderia haver inovação declarada.

Mas o que Caio Prado entende por "natureza", para que esta tenha um "comportamento" dialético? Uma primeira resposta é que "a natureza [...] é a realidade objeto do pensamento e do conhecimento humano"; ou seja, por "natureza" ele define em geral o "objeto do conhecimento", "a realidade" contraposta ao "pensamento", e não necessariamente uma dimensão desta realidade, a saber, a que se distingue dos fatos históricos e sociais, como na terminologia tradicional.

E se, por outro lado, num sentido mais estrito "natureza" indica a parte da realidade distinta daquela povoada pelo histórico e social, aí também ela não se confunde com a definição clássica de algo estático, porque, em vez de coisas inertes e individuais,

a Dialética [...] considera antes as relações, o "conjunto" e a "unidade" universal donde decorrem tais relações; e é nessas relações, sejam no espaço, sejam no tempo (quando mais propriamente elas se denominam "processos"), é nelas que a Dialética vai procurar e determinar os "indivíduos" e sua "individualidade" própria.

As coisas e os eventos individuais não o são por si mesmos, mas como resultado de "relações" que, quando se dão "no tempo", "se denominam processos". A natureza já é processual.

Assim, o método dialético seria a identificação de relações reais pelo sujeito do conhecimento, relações em que os fatos são produzidos, desdobrando no tempo a individuação dos eventos. Por tal desdobramento a natureza se reveste de um caráter processual, à semelhança da história. Só nesse sentido seria possível falar realmente de uma "dialética da natureza", porque até nela "as feições" estão em "permanente transformação". Por oposição à perspectiva que naturaliza a história, encontrando também aí apenas mecanismos e coisas, a dialética como que historiciza a natureza.

Mais exatamente, Caio Prado diz que "os fatos da Natureza extrahumana também têm a sua história. [...] enfim toda a Natureza orgânica e inorgânica tem sua história" na sucessão dos seus eventos. Como esta historicidade não é visível em todo o real, “o pensamento metafísico é levado a introduzir em tal história aparentemente periódica a noção de 'ciclos' idênticos", procedimento que é "possível e apresenta à primeira vista alguns visos de justeza, porque a natureza histórica de grande parte

5 Idem. Dialética do conhecimento. $3^{\mathrm{a}}$ ed. São Paulo: Brasiliense, 1960. tomo I, p. 10. 
dos fatos do Universo, isto é, a verdadeira história que introduz permanentemente o novo, essa história é freqüentemente imperceptível, na escala humana" . O caráter cíclico observado nos fenômenos naturais só "aparentemente" é histórico, pois a "verdadeira história" é a "que introduz permanentemente o novo" e não a repetição previsível pela periodicidade, em que nada de diferente se produz. Mas “a história humana, pelo contrário, desenvolvendo-se na nossa escala e tão próxima de nós, revela desde logo seu caráter verdadeiro", a saber, aquele que produz algo "novo", a relação processual que liga o passado ao futuro pela diferença.

Nem a história natural é cíclica; ela aparenta sê-lo somente porque a "escala humana" é muito pequena para que o aparecimento do novo seja "perceptível" nos fatos do universo. Daí ser a história humana a dimensão privilegiada em que fica evidente, pela "escala tão próxima de nós", que algo diferente surge de uma relação, surge do seu oposto, dialeticamente, como processo que liga e distingue passado e futuro - "notamos, tanto a propósito de Hegel como de Marx, que aquela maneira de tratamento é sugerida sobretudo pela consideração da história humana". É essa história que deve assim ser considerada "sobretudo", porque "revela [...] o caráter verdadeiro" do tempo histórico.

Quando se naturaliza a história humana, ao contrário, o que se faz é generalizar uma concepção cíclica do tempo que até para a história natural é uma simplificação, pois apresenta "um aglomerado de situações dispostas no tempo e sem outra ligação umas com as outras a não ser a da própria sucessão e de seu parâmetro abstrato e puramente conceptual"9. Ou seja, esta concepção parte de "situações [...] sem ligação umas com as outras", já dadas em sua individualidade, e as relaciona apenas porque as "dispõe" numa sucessão em que o tempo é um "parâmetro" externo às situações mesmas e, daí, "abstrato". Em vez disso, a concepção dialética parte de relações que, na contradição dos seus termos, individuam as situações e articulam uma temporalidade processual, um tempo histórico, porque concreto.

Por isso, Caio Prado afirma:

Logo se vê o aspecto essencialmente revolucionário da História observada e interpretada através da Dialética. [...] Cada um dos momentos dessa história, cada uma de suas fases ou situações traz no seu seio a transformação que a destruirá; transformação que não vem do seu

6 Ibidem. tomo II, p. 519.

7 Ibidem. tomo II, p. 520.

8 Ibidem. tomo II, p. 518.

9 Ibidem. tomo II, p. 520, grifo meu. 
exterior, que não é diferente dela própria, mas é ela mesma no seu desenvolvimento. ${ }^{10}$

Mudando um pouco os termos, como "a transformação que destruirá" "cada uma de suas fases ou situações" já vem "no seio" delas, ocorre uma espécie de interiorização da própria "transformação, que não vem do exterior". E como "não vem do exterior", "não é diferente dela própria, mas é ela mesma", a saber, a "fase ou situação", não tomada como algo isolado e extático e sim "no seu desenvolvimento". A dialética dissolve assim inclusive a dicotomia entre exterior e interior, interiorizando o princípio transformador do real no próprio real: a "destruição" de um "momento da história" é a expressão da negatividade inscrita neste momento mesmo; e o "desenvolvimento" é a emergência de uma nova "fase ou situação" a partir da destruição da anterior.

Esta explicação da "permanente transformação" e "mutabilidade" pela dialética, isto é, pela relação que "entrosa" o que é "distinto" - nos termos do primeiro texto citado acima (nota 3) -, é feita na Dialética do conhecimento mediante uma longa exposição do pensamento de Hegel, notável por ter sido escrita num tempo em que, ao contrário do nosso, era escasso o recurso aos comentadores da obra do filósofo alemão ${ }^{11}$. A preocupação em ser fiel à importância dessa obra talvez tenha contribuído para a acusação de "hegeliano" feita a Caio Prado, como vimos também no texto mencionado à nota 3 .

De qualquer modo, dizíamos, cada "fase ou situação" contém em si o princípio transformador de que surge o "novo", o histórico propriamente dito. Este princípio transformador é que foi chamado por Hegel de elemento "racional" inscrito, portanto, no próprio "real". Daí que a exposição da sua filosofia por Caio Prado seja feita justamente por este caminho e nestes termos: "O Real é Racional”, famosa proposição da Filosofia do Direito escrita em 1821. Sem querer entrar no detalhe da exposição que daí decorre, basta aqui recapitular o movimento geral.

Em primeiro lugar, o "real é racional” porque se realiza "pela ação racional do homem" ${ }^{12}$, e não por uma lógica abstrata, como afirmam as caricaturas de Hegel feitas por alguns materialistas. É o sujeito da história, o homem em sua "ação", que se projeta "racionalmente" e tenta realizar seu plano; na medida em que o consegue, torna-o "real". Mas esta realização

10 Ibidem. tomo II, p. 438.

11 Além da obra de Croce, Caio Prado cita Jean Hyppolite, cujo estudo seminal sobre a Fenomenologia do Espírito havia sido publicado na França pouco tempo antes, em 1946 (Cf., por exemplo, p. 363, nota 291).

12 PRADO JR, Caio. Dialética do conhecimento. Op. cit. tomo II, p. 377, grifo meu. 
nunca é plena, nunca é definitiva. Caio Prado afirma que "uma vez realizado, o Real torna-se 'outro' com relação à Razão; é exterior a ela, tornou-se independente; e nesse sentido opõe-se à Razão; e na qualidade de oposição, é Necessário, isto é, independe da Razão e da 'vontade' do homem". Ou seja, embora uma situação histórica possa ser resultado de um projeto "racional" voluntário e consciente, sua existência envolve elementos que escapam ao plano original e que aparecem a este como algo de "outro", de "exterior", de "independente". A "razão" não se reconhece plenamente nesta realidade e, por outro lado, a considera como uma contingência inevitável, "necessária", sobre a qual deve exercer em seguida a sua crítica "racional": "Em face desse novo Real independente e Necessário, a Razão se afirma novamente e com isso o nega. O Real deixa então de ser Racional - pois é negado pela Razão." É importante observar aqui o reconhecimento de que, contrariando a fórmula que os críticos de Hegel pensam ser rígida, o "real" pode "deixar de ser racional"; e este é justamente o momento da crítica, em que a "razão" condena, "nega" a realidade existente. O texto conclui: "e deixando de ser Racional, deixa também de ser Necessário, para logo deixar de ser também Real. Está em vias de perecimento, porque em frente dele constitui-se outro Racional que será o novo Real que substituirá o antigo moribundo" ${ }^{13}$. O efeito prático da crítica "racional" é enxergar que a realidade existente poderia ser distinta, por não ser ela mesma "racional", apenas uma contingência. Ela então "deixa de ser Necessária” e passa a ser objeto de uma ação revolucionária pela qual ela "logo deixa de ser também Real". Será substituída por um "novo Real", fruto do "outro Racional”, de um novo projeto crítico e revolucionário.

O próprio Caio Prado rebate esta exposição abstrata para o plano da história nos seguintes termos:

É nesse processo, nessa dialética da história apontada por Hegel que as situações (a que o filósofo se refere, na qualidade de idealista, como Idéias) se fazem de Racionais, Necessárias e Reais, em Irracionais, Não-necessárias e Irreais, por efeito da oposição de outras que se formam em seu próprio seio e que passam a encarnar a Racionalidade (porque são produto da ação racional do homem), a Necessidade (porque uma vez constituídas independem já da vontade humana) e naturalmente a Realidade, uma vez que passam a existir; Racionalidade, Necessidade e Realidade que antes cabiam às que as precederam e que se aniquilam na morte. ${ }^{14}$

13 Ibidem. tomo II, p. 377.

14 Ibidem. tomo II, p. 378. 
É crucial observarmos que nessa descrição a "racionalidade" e a "necessidade" das situações históricas se configuram enquanto essas situações são "reais", e não como uma razão em si mesma, externa à história. Pois elas justamente perderão o seu título e sua majestade diante da crítica de uma nova "racionalidade" e "se aniquilarão na morte"; "morte" não apenas de uma "realidade", mas sim, com ela, de sua "razão" de ser.

A Dialética do conhecimento criticará a seguir a perspectiva idealista de Hegel e passará a expor a materialista de Marx e Engels, mas conservará da primeira alguns resultados fundamentais, como a forma do movimento da história que acabamos de examinar. Não é na relação dialética entre o "real" e o "racional" que radica o idealismo a ser superado, e sim no que "se refere" às situações históricas "como Idéias". O Idealismo erra ao transformar os projetos "racionais" dos agentes em "idéias" independentes deles, dotadas de uma lógica própria e, assim, desvinculadas dos sujeitos individuais e associadas a um sujeito universal, que Hegel chamava de "espírito do mundo" (Welgeist). Mas se a "razão" for considerada como aquele projeto dos agentes, a dialética do "real" e do "racional" decorre nos termos descritos por Hegel.

Numa formulação simples, Caio Prado resume o momento seguinte: "Na verdade o que se passou foi que Marx, com sua formação hegeliana, aplicou aos fatos concretos e exteriores o mesmo tratamento que Hegel aplicara à Idéia" ${ }^{\text {. }} \mathrm{O}$ "tratamento" em si não mudaria, apenas seu objeto. E qual seria ele? A que "fatos concretos e exteriores" Marx teria "aplicado" a dialética? O texto afirma que "a germinação da semente da Dialética lançada por Hegel ocorrerá com seus discípulos e sucessores Marx e Engels; e as condições necessárias para isso serão dadas pelas circunstâncias históricas do momento, a saber, a profunda transformação social em curso na Europa por efeito da revolução industrial iniciada no século XVIII e o conseqüente aparecimento de uma nova classe social em rápido crescimento e desenvolvimento, o proletariado industrial"16. As novas "circunstâncias históricas" haviam inviabilizado o Idealismo hegeliano, com suas conciliações, e reforçado o aspecto contraditório da sociedade. Agora, "trata-se essencialmente, em Marx e Engels, da questão do proletariado" e da luta de classes. Daí, "essas considerações permitem a Marx e Engels passar da noção de classes e da oposição de operários e capitalistas [...] para outra identidade que é o Capitalismo" ", isto é, a "oposição" entre trabalho

15 Ibidem. tomo II, p. 492.

16 Idem. Notas introdutórias à lógica dialética. Op. cit. p. 25.

17 Ibidem. p. 26 e 28 respectivamente, grifo do autor. O texto explica assim a "identidade": “a identidade do capitalismo não é dada apenas 'em si', como determinado regime econômico e social, mas em função das relações que o estruturam e compõem. Isso 
e capital. Esta oposição de base aparece como "aquele fato elementar da troca [...] que vai revelar toda a estrutura da economia capitalista” e, a partir dela, conformar "as relações estabelecidas entre os homens, e as de produção em particular - relações de empregado a empregador, de comprador a vendedor, de prestamista a credor - [...] em perpétuo 'devenir' e transformando-se permanentemente" ${ }^{\prime 18}$.

A dialética agora reflete oposições reais do capitalismo, que o definem como uma "identidade" dialética, como um sistema social que configura "as relações estabelecidas entre os homens" em cada nível ou esfera de desdobramento - na troca simples, no crédito, na produção etc. São as várias esferas de "realidade", desdobradas pelo movimento da contradição que constitui o capital e pelo motivo do lucro que o anima, como sua razão de ser. "Independente da Razão e da 'vontade' do homem", como dizia o comentário sobre Hegel citado acima (nota 12), há aqui já uma "razão" neste "real" capitalista. Além dela, evidentemente, acrescentam-se as "razões" dos agentes, com graus múltiplos de consciência do sistema e de "vontade" de enquadrar-se a ele ou de modificá-lo conforme a posição designada pelo sistema a cada agente ou grupo de agentes. Mas conscientemente ou não, todas essas "razões" acabam operando dentro das condições determinadas pela "razão" de ser do capitalismo em uma configuração histórica específica, no movimento de identificação e diferenciação entre o "real" e o "racional" descrito acima, a propósito de Hegel.

Pode-se dizer, portanto, que desta dialética entre a "razão" proposta pelo agente histórico e a "razão" realizada no todo social se forma algo como o "sentido" de uma configuração histórica: ele é justamente o "racional" possível no "real” da história. Neste ponto, porém, é preciso especial consideração, devendo ser dedicado a ele um item à parte, com o qual se concluirá o presente ensaio.

\section{Dialética do Sentido}

É bem conhecida a importância do conceito de "sentido" na história colonial contada na Formação do Brasil contemporâneo ${ }^{19}$. Já na seqüência

permite a Marx e Engels revelar o não-ser, a negação desse Capitalismo [...]; negação essa que deve estar incluída e implícita nas próprias relações que estruturam e representam a identidade do Capitalismo". Trata-se de uma "identidade" dialética, portanto.

18 PRADO JR, Caio. Dialética do conhecimento. $3^{\text {a }}$ ed. Op. cit. tomo II, pp. 489 e 486 respectivamente.

19 É interessante observar que a palavra "sentido", que chegou a merecer todo um capítulo introdutório de discussão metodológica na obra de 1942, tenha perdido bastante 
da introdução do livro é discutida a função metodológica deste conceito, baseada na sua presença na realidade, caracterizando os fatos: "Todo povo tem na sua evolução, visto à distância, um certo 'sentido"', é a famosa frase de abertura; o "sentido" está, explica-se a seguir, "no conjunto dos fatos e acontecimentos essenciais que a constituem [a história de um povo] num largo período de tempo" ". Trata-se de algo "essencial", distinto do que o texto chama de "pormenores" e de "cipoal de incidentes secundários" de "fundamental e permanente" ${ }^{22}$, a "essência de nossa formação" "constitui" uma história, imprimindo a ela como que um "caráter" 24 .

A história brasileira, em particular, terá o sentido de uma "empresa comercial”, pois "nos constituímos para fornecer açúcar, tabaco, alguns outros gêneros; mais tarde ouro e diamantes; depois, algodão, e em seguida café, para o comércio europeu. Nada mais que isto. [...] Tudo se disporá naquele sentido" ${ }^{25}$.

A ênfase desse trecho pode parecer exagerada e, daí, polêmica - "nada mais que isto", "tudo se disporá naquele sentido". De fato, talvez tenha havido aqui a intenção de realçar a presença e a força formadora do "sentido". Só que essa ênfase tem de ser entendida, ela mesma, no contexto do debate político sobre os rumos que o Brasil do século XX deveria tomar, tentando reverter o quadro da dependência externa diagnosticado por Caio Prado nas décadas de 1930 e 1940. Mas até que ponto o conceito mesmo de "sentido" é inevitavelmente unilateral, não podendo ser formulado sem uma fatal simplificação?

À luz dos textos de cunho filosófico e metodológico que vínhamos examinando, o conceito ganha mais densidade. Vimos que ele ali aparecia no âmbito da dialética entre a ação dos indivíduos e a "razão" capitalista que identifica esse sistema pela sua autonegação. Retomando a questão proposta, até que ponto essa "razão" seria um "sentido" determinante e

\footnotetext{
importância depois, para reaparecer apenas em 1959, e no contexto de uma discussão sobre "lógica dialética". Na História econômica do Brasil, de 1945, com efeito, Caio Prado fala do "caráter da formação econômica brasileira", título do capítulo 2, e a palavra "sentido" só aparece no fim do capítulo, em que praticamente ele cita o texto da Formação do Brasil contemporâneo. No livro de 1945, porém, o conceito de "caráter" não vem acompanhado da discussão metodológica do livro de 1942. Talvez, como foi sugerido no começo do presente texto, Caio Prado tenha preferido reservar esta discussão para uma obra que tratasse propriamente da questão do conhecimento, o que fez na década de 1950.

20 PRADO JR, Caio. Formação do Brasil contemporâneo. 23ª ed. São Paulo: Brasiliense, 1994. p. 19, grifos meus.

22 Ibidem. p. 20.

23 Ibidem. p. 31.

24 Ibidem. Cf., por exemplo, p. 22 e p. 29.

25 Ibidem. p. 31-32.
}

21 Ibidem. p. 19. 
unilateral, tornando insignificantes, por exemplo, as ações dos indivíduos? Caio Prado afirma que

a deliberação e ação individual [...] são livres; mas o seu "sentido" profundo, a função social que vão desempenhar e a resultante que derivará delas, isso se encontra predeterminado pelas circunstâncias sociais do tempo e lugar em que a ação é executada; e é condicionado pelo processo histórico particular de que a ação forma uma das componentes, bem como pelas contradições que constituem o dinamismo daquele processo. ${ }^{26}$

Aparentemente, "as circunstâncias sociais" "predeterminam", talvez até de modo absoluto, o que os indivíduos fazem e deliberam como "o seu 'sentido' profundo, [sua] função social”. Examinemos a questão mais de perto, analisando o texto.

Em primeiro lugar, o que "condiciona” a ação dos indivíduos é o "processo histórico particular [...] bem como (as) contradições que constituem o dinamismo daquele processo"; ou seja, também são as "contradições"; ou, melhor ainda, são elas, na medida em "que constituem o dinamismo daquele processo". O processo não é "constituído" por uma força única e unilateral, portanto, mas por "contradições", o que é dito mais claramente numa passagem anterior: "É no âmbito de um tal processo que assim se desenvolve através de contradições que superadas vão dar em mudanças de situação e na eclosão de novas contradições, é aí que se realiza a ação dos indivíduos"27. Os indivíduos não agem empurrados por forças unilaterais: eles agem "aí", situados num "tempo e lugar" abertos por um processo; mais, por um processo que não é unilateral, mas "se desenvolve através de contradições", isto é, pela oposição dialética de forças sociais reais - a realidade, enquanto "processo", não é homogênea, e sim conflituosa; por fim, "processo" implica "mudanças de situação e [...] eclosão de novas contradições". É em meio a conflitos e "mudanças de situação" que os indivíduos agem.

E tais características da realidade histórica - contraditória e cambiante - repercutem não apenas sobre o problema do indivíduo diante do todo social, como também sobre a questão mais ampla da unilateralidade do "sentido" histórico. "Contradição" implica aqui que a realidade é composta por forças sociais “opostas”, e não por uma força única ou fatalmente predominante; o predomínio que está associado ao "sentido" pode muito bem ser, usando palavras do autor (no texto citado à nota 25), uma "resultante", sempre incerta do conflito das forças opostas. Logo no começo da Formação

26 PRADO JR, Caio. Dialética do conhecimento. Op. cit. tomo II, p. 549-550.

27 Ibidem. tomo II, p. 549. 
do Brasil contemporâneo, aliás, em seguida à definição do "sentido", é dito que "o sentido da evolução de um povo pode variar; acontecimentos estranhos a ele, transformações internas profundas do seu equilíbrio ou estrutura, ou mesmo ambas estas circunstâncias conjuntamente, poderão intervir, desviando-o para outras vias até então ignoradas" ${ }^{\prime 2}$. As tendências predominantes que determinam um "sentido", contraditoriamente, podem engendrar tendências opostas na "estrutura" do sistema, donde o caráter "interno" das transformações decorrentes.

Mas há um segundo aspecto no problema além deste primeiro, relativo ao caráter contraditório e cambiante da realidade. O conceito de "sentido" está inevitavelmente associado a valores, finalidades, intenções, consciência enfim. Voltando ao nível do indivíduo diante do todo social, "verifica-se portanto que o conhecimento do dinamismo dos fatos históricos e a consciência que com ele os homens adquirem de seu eventual destino e das conseqüências gerais de sua ação, aquele conhecimento se faz fator determinante do sentido da ação e dos fatos sociais" ${ }^{29}$. Os indivíduos não agem cegamente, inconscientes das forças sociais em conflito e das tendências predominantes, mas com graus variados de percepção do conjunto em que se situam, relacionando suas "razões" particulares à "razão" geral, como vimos no fim do item anterior. A "consciência" que "adquirem do seu eventual destino" orienta as suas ações pró ou contra este "destino"; é ela que configura o "sentido da ação e dos fatos sociais", e não uma força cega. O conceito de "sentido" assume plenamente deste modo a conotação de "significado",

e isso de maneira tanto mais rigorosa e precisa e com tanto mais acerto e sucesso quanto aquele conhecimento for maior, a consciência dos indivíduos agentes mais clara, e portanto a sua expressão normativa for mais completa e corretamente formulada; isto é, que a norma de ação exprima de um lado mais adequadamente o dinamismo histórico-social do momento a que se aplica e doutro apresente dentro desse dinamismo e seu sentido a perspectiva mais favorável e conveniente aos indivíduos a que ela se dirige. ${ }^{30}$

A consciência do "sentido" pelos agentes alcança assim uma "expressão normativa", ganhando força social; o "dinamismo histórico-social" se "exprime" como "norma de ação", deixando de ser força cega; o "sentido" passa a ser valor compartilhado por um grupo de indivíduos ${ }^{31}$.

28 PRADO JR, Caio. Formação do Brasil contemporâneo. Op. cit. p. 19.

29 Idem. Dialética do conhecimento. Op. cit. tomo II, p. 551, grifo do autor.

3o Ibidem. tomo II, p. 551, grifo do autor.

31 Pode-se entender dessa forma a passagem da Formação do Brasil contemporâneo em que o sentido aparece como "o espírito com que os povos da Europa abordam a América. 
E é enquanto "norma" que o "sentido" ultrapassa o nível da mera orientação das ações e adquire uma dimensão epistemológica. Caio Prado afirma que "a norma de ação humana e dos fatos sociais só pode portanto ser um método de interpretação da história”, uma vez que não pode estar acima da sua historicidade, funcionando "à feição da Moral e do Direito propostos pela Metafísica"; ou, ainda, que "a norma ou método histórico não é pois outra coisa no mundo de hoje que a 'consciência da forma do movimento da história' para usar da definição de Hegel"

Elevado à consciência social como uma "norma", o "movimento da história" permite uma "interpretação da história", que é justamente a função metodológica do conceito de "sentido". Daí que ele tenha essa função na Formação do Brasil contemporâneo, onde "quem observa" a história pelo seu sentido poderá “desbastar o cipoal dos incidentes secundários” e "não deixará de perceber que ele se forma de uma linha mestra" ${ }^{3}$; onde o historiador é admoestado a "reconstituir o conjunto de nossa formação, colocando-a no amplo quadro" ${ }^{34}$. Atente-se para as palavras grifadas “observar”, “desbastar", "perceber”, "reconstituir”, “colocar”: há sempre aí uma operação do sujeito do conhecimento.

Por isso também o conhecimento histórico é apresentado como "interpretação". Pois todo o problema consiste em encontrar "um critério geral de interpretação dos fatos, em que se conciliem os aspectos contraditórios em que se apresenta a Natureza"35. Novamente, chamo a atenção para as palavras decisivas que destaquei no texto: "critério", "interpretação", "conciliação". Por princípio, elas têm a ver com o sujeito do conhecimento, com a sua liberdade relativa em compor o todo da realidade conforme um ou outro "sentido". Mas isso não quer dizer que haja aqui qualquer subjetivismo. A "interpretação" não deve inventar sentidos, e sim limitar-se a encontrar o "critério" pelo qual os lados opostos da realidade se "conciliam" na própria realidade. Como vimos, esta tem "aspectos contraditórios", não sendo nunca unívoca. Por outro lado, o que a "interpretação" faz é formular o "sentido", ou seja, o "critério" conforme o qual a contradição real se “concilia", articulando-se de algum modo.

Essa articulação é a função metodológica do "sentido", de acordo com as Notas introdutórias à lógica dialética:

A idéia de povoar não ocorre inicialmente a nenhum.", p. 23. "Espírito" e "idéia" aparecem aqui como forma da consciència social do "sentido" histórico. PRADO JR., Caio. Dialética do conhecimento. Op. cit. tomo II, p. 552.

33 Idem. Formação do Brasil contemporâneo. Op. cit. p. 19, grifos meus.

34. Ibidem. p. 20, grifos meus.

35 Idem. Notas introdutórias à lógica dialética. Op. cit. p. 12, grifos meus. 
o conhecimento científico não se constitui de um aglomerado de conceitos individualizados e dispostos entre si por justaposição. E sim se compõe de um sistema de conjunto cujas partes, que seriam os conceitos particulares, reciprocamente se incluem umas nas outras, e têm sentido e conteúdo unicamente dentro do sistema em que se integram, e em função dele. ${ }^{36}$

Mais uma vez, só que agora no plano epistemológico, aparece a crítica à "justaposição" de termos "individualizados", que aqui são "conceitos". No lugar dessa unidade externa, desse mero "aglomerado" de indivíduos sem relação mútua, o "conhecimento científico" é formado pelo "sistema de conjunto" de suas partes, da relação interna entre os termos componentes, pelo qual os conceitos "têm sentido". Ao encontrar o "sistema" em que as "partes [...] reciprocamente se incluem umas nas outras", a interpretação alcança o "critério" de "conciliação" das oposições reais do objeto estudado, o seu "sentido" como "resultante" das forças antagônicas.

Mas "a norma de ação humana, a interpretação da História, o Marxismo, em suma, é a tradução do autodinamismo ou dialética dos fatos humanos numa lei do pensamento móvel, no movimento próprio do pensamento; e é isso a Lógica dialética, a Dialética como método lógico" ${ }^{77}$. Assim, nem os conceitos são termos independentes, que uma "interpretação" poderia reunir de diversos modos, nem é variável a sua reunião num "sentido", que sempre poderia ser outro. A “interpretação da história” não é arbitrária; ela deve "traduzir" o "sentido" real "no movimento próprio do pensamento". E este pensamento, portanto, só pode ser "móvel”, porque é dialético o "autodinamismo [...] dos fatos humanos". A "interpretação da história" deve "traduzir" um "autodinamismo [...] dialético", deve expressar não apenas o predomínio de uma das forças em luta, mas a luta mesma das forças opostas, da qual resulta um "sentido" sempre mutável.

Disso tudo pode-se perfeitamente concluir que, na medida em que a "norma de ação" dos próprios agentes históricos é que passa a ser "critério" de interpretação do historiador, estabelecendo como que uma ponte entre a dimensão real e a metodológica, em ambas ocorre um processo de normatização, de imposição de sentido. Na dimensão da realidade histórica, deve ser lembrado aquele primeiro aspecto do "sentido" visto acima, a saber, o de que as forças sociais estão sempre em conflito e transformação. Assim, o próprio pensamento dos agentes, o "espírito" ou "idéia" que norteia as suas ações (cf. nota 31), capta a força social "resultante" e a transfigura em

36 Ibidem. p. 66-67, grifo meu.

37 Idem. Dialética do conhecimento. Op. cit. tomo II, p. 552. 
valor ou "norma"; o que não quer dizer que apenas esta força e este sentido existam em uma realidade determinada, senão ela não seria conflituosa. Por outro lado, ao passar para o método do historiador, esta "norma" lhe é imposta como "sentido" de uma situação histórica. Mas haveria aí também uma normatização, isto é, uma espécie de simplificação de um todo social sempre mais complexo? Examinemos, por fim, estes dois pontos.

Em relação ao primeiro, ou seja, que os próprios agentes simplificam a realidade ao reconhecer nela um "sentido" fundamental, pode-se citar a análise dos ideais liberais feita por Caio Prado na Dialética do conhecimento. Estes ideais se originaram da luta contra os privilégios absolutistas e feudais. Mas "essa luta contra os privilégios não era tão simples como poderá parecer a quem os considera unicamente em si e isoladamente. Atrás deles se abrigava toda uma estrutura política e jurídica complexa de que os privilégios não representavam senão um aspecto particular e mais aparente" ${ }^{38}$. A realidade social do Antigo Regime era mais "complexa" do que podia "parecer a quem" a compreendesse apenas do ponto de vista de um sentido, no caso, da luta contra os privilégios. Por mais "aparente" e decisiva que fosse, essa luta constituía apenas "um aspecto particular" ao lado do qual havia outros. Mas justamente por ser o "mais aparente" é que ela permitia a configuração do sentido da ação revolucionária, escondendo aspectos menos ou não "aparentes".

Por isso, continua o texto,

disfarçando-se embora, para os efeitos práticos de propaganda, e de maneira mais ou menos velada e inconsciente atrás da luta popular contra os privilégios, o ataque em conjunto às instituições do Antigo Regime era decorrência natural daquela luta: não era possível mexer numa só de suas peças sem afetar as demais partes e o conjunto. Daí toda a ordem de contradições e incoerências aparentes que ocorrem sempre em situações semelhantes, e que tornam tão complexa a interpretação do historiador e a tarefa do político. ${ }^{39}$

Em primeiro lugar, o "ataque" liberal não era algo arbitrário, mas "decorrência natural" de uma situação de conjunto em que os privilégios não podiam mais se sustentar; e "decorria" como força "resultante" do conflito de forças, sendo assim o seu "sentido" fundamental. Entretanto, em segundo lugar, como a situação era "complexa", esta "norma" consciente acarretava conseqüências imprevistas, "veladas e inconscientes" aos agentes históricos. Donde as "contradições e incoerências” inevitáveis

38 Ibidem. tomo II, p. 455.

39 Ibidem. tomo II, p. 455. 
nas "normas" orientadoras da "tarefa do político", o fato de um sentido "disfarçar" outros.

E tais “contradições e incoerências” também "tornam tão complexa a interpretação do historiador", entrando agora no segundo ponto indicado acima, a saber: a possível simplificação que o "sentido" de uma situação impõe inclusive ao conhecimento. Prosseguindo sua análise do liberalismo, Caio Prado afirma que

Liberdade e Igualdade apresentavam-se assim com um duplo aspecto e sentido: de um lado, eram armas ideológicas voltadas contra os antigos e odiados privilégios que ainda crepitavam com o lusco-fusco de brasas que se apagam; mas de outro, constituem os fundamentos sobre que se estruturavam novos privilégios tão odiados como os antigos. E não havia, dentro das concepções clássicas do racionalismo metafísico, como separar aqueles dois aspectos aproveitando-se de um e descartando-se do outro: eram como imagem refletida em espelho refletor ${ }^{40}$.

Como quase sempre, o "sentido" destes valores era "duplo" e indissociável, reportando-se cada qual a um momento da mesma situação em que se configurava a realidade "complexa". O elemento "ideológico" da norma liberal estava em desconhecer o outro lado, simplificando o conjunto em um dos seus "aspectos particulares", considerando-os "unicamente em si e isoladamente". E isso era inevitável para o liberalismo, associado ao "racionalismo metafísico" que não conseguia levar em conta os dois aspectos em sua unidade contraditória.

O historiador preso a tal concepção do conhecimento, portanto, também ficará enredado no dilema entre a simplificação de um "critério de interpretação" único e as "contradições e incoerências" advindas de tentar separar o que é inseparável. Só a perspectiva dialética permitirá a ele assumir a contradição do "duplo sentido", encontrando o "critério geral de interpretação dos fatos, em que se conciliem os aspectos contraditórios", conforme passagem citada antes (à nota 35). Daí a elaboração de um "critério de verdade" histórico, "relativo" a cada momento de uma situação complexa ${ }^{41}$. O próprio conceito de "verdade" não é absoluto, então, definindo-se pela historicidade e, mais ainda, pela contradição dos momentos históricos.

Decorreria disso que o "sentido", como articulação ou "verdade" dos conceitos relativos a uma formação social, seria único apenas dentro deste critério, traduzindo a simplificação pela qual os próprios agentes pautam

40 Ibidem. tomo II, p. 457, grifos meus.

41 Cf. Ibidem. tomo II, p. 634-635. 
as suas "tarefas". O historiador dialético deve indicar este "sentido" pelo qual as forças sociais que estuda resolveram na prática as "contradições e incoerências" em que se encontravam, articulando-se numa situação histórica específica. Não será uma simplificação, na medida em que o "sentido" for explicitado como "resultante" deste conflito, até para que de sua dinâmica própria possa ser explicada a superação do "sentido" e sua transformação interna.

Caio Prado não chega a tanto, talvez não tenha ousado tanto, preferindo limitar-se a afirmações gerais sobre a "relatividade da verdade", isto é, a sucessão temporal de verdades, distintas mas válidas em cada etapa. A conclusão se impõe, contudo, como o termo final de um silogismo do qual só se tivessem os dois primeiros enunciados. $\mathrm{E}$ a partir dela fica sugerido um caminho para a reflexão e a avaliação retroativa de suas idéias sobre o hoje controvertido "sentido da colonização", tema bem mais complexo e sofisticado se compreendido na chave dialética proposta pelo próprio autor. Essa poderia, enfim, converter-se na tarefa que "torna tão complexa a interpretação do historiador", especialmente daquele que pretende seguir tais pegadas. 


\section{Datas de recebimento e aprovação dos artigos desta edição}

Cinema = Cavação:

Cendroswald Produções Cinematográficas

Carlos Augusto Calil

Recebido em 8 de junho de 2008

Aprovado em 6 de agosto de 2008

O lobisomem entre índios e brancos:

o trabalho da imaginação no Grão-Pará no final do século XVIII

Mark Harris

Recebido em 28 de abril de 2008

Aprovado em 29 de junho de 2008

A teoria da história de Caio Prado Jr.:

dialética e sentido

Jorge Grespan

Recebido em 1 de abril de 2008

Aprovado em 2 de maio de 2008

Caio Prado Jr. e a história agrária do Brasil e do México

Guillermo Palacios

Recebido em 27 de março de 2008

Aprovado em 12 de maio de 2008

Fronteiras da desordem:

saber e ofício nas experiências de Hélio Oiticica no Morro da Mangueira e de Carlos Nelson Ferreira dos Santos em Brás de Pina

Magaly Marques Pulhez

Recebido em 17 de abril de 2008

Aprovado em 24 de junho de 2008

"O linguajar multifário":

os estrangeiros e suas línguas na ficção de Mário de Andrade

Maria Caterina Pincherle

Recebido em 20 de março de 2007

Aprovado em 6 de agosto de 2008

Os nomes da língua:

configuração e desdobramentos do debate sobre a língua brasileira no século XIX

Olga Ferreira Coelho

Recebido em 26 de maio de 2007

Aprovado em 6 de agosto de 2008

Caetés:

nossa gente é sem herói

Erwin Torralbo Gimenez

Recebido em 5 de janeiro de 2007

Aprovado em 6 de agosto de 2008 